\title{
AN ANALYSIS OF FIGURATIVE LANGUAGE FOUND IN KATY PERRY'S SONG ENTITLED "FIREWORK"
}

\author{
Putu Ratna Arditami \\ Ganesha University of Education \\ e-mail: ratnaarditami97@gmail.com
}

\begin{abstract}
The existence of figurative language as a way of conveying utterance other than its ordinary way helps the song writer in composing and producing beautiful songs. By using figurative language, the singer could deliver the messages existed in a song in a brief yet meaningful way. Furthermore a song entitled "Firework" attracts the researcher's attention in doing analysis about the types of figurative language. This study then focuses on analyzing the types of figurative language and its meaning found in the song lyric entitled "Firework" by Katy Perry. The aims of the study are to identify and describe the meaning of the types of figurative language used in the song "Firework". This study implements descriptive qualitative method. The data of the study is the song lyric entitled "Firework" by Katy Perry which is taken from azlyrics.com. This study applies study documentation as the method in collecting the data. The result of data analysis shows that there are six types of figurative language found in the song lyric entitled "Firework" by Katy Perry. They are symbol, hyperbole, simile, personification, metaphor, and paradox. Furthermore, the meaning of these types of figurative language is also described by the researcher.
\end{abstract}

Keywords: figurative language, types of figurative language, meaning, song

\section{INTRODUCTION}

Language is believed as the bridge that could connect humans and nations. The existence of language helps people to express their thoughts, ideas, and feelings or even build a good relationship with one and another. Language is used widely by many people who do not share the same language to build communication (Harmer, 2006). The communication in which the people who do not share the same language could happen regarding to the fact that a language conveys meaning in the utterance that is uttered by the speaker.

Furthermore, in order to make the communication goes well, there must be a good understanding between the two speakers in catching the meaning that existed behind the utterances uttered by these speakers by using their own language. However, regarding to this situation, people do not always have the same ability in catching the meaning existed behind an utterance. Miscommunication then might occur as the result that people fail in interpreting the meaning behind the utterance. This then becomes the fact that people do not only face difficulty in interpreting the meaning, but they also find difficulty in expressing their thought, in which it makes miscommunication occurs in a conversation.

Those conditions above then make literature born. It is believed that literature born due to the lack of human in expressing themselves (Semi, 2012). Then, since the time of the literature is born, it could bring positive effect to human's life in terms of expressing their thoughts, ideas, and feelings. According to Perrine (1982), fiction, drama, and also poetry are three things which belong to kinds of literature's work. Furthermore, between these three kinds of literature's work, the poetry is always interesting to be discussed. It is because poetry does not always have to be read, but it also can be sung. Therefore, many song writers then create the song lyrics which are inspired from poetry. This then makes song is a part of literature's work. 
Furthermore, in understanding what is meant by the song writer in his/her song is not always easy. This is because in creating a beautiful song, a song writer tends to use figurative language to convey or cover the literal meaning by using different way. Therefore, in understanding the literal meaning of the song, the listeners should have further knowledge about figurative language.

Research in relation to the figurative language has been done by many researchers. A descriptive qualitative research conducted by Siallagan, Manurung, \& Sinaga (2017) was to analyze the kinds of figurative language and imagery in Taylor Swift's songs. The findings showed that there are thirteen songs examined by the researchers, and it is found out that there are eight kinds of figurative languages and six kinds of imagery used in Taylor Swift's songs. The figurative languages are personification, metaphors, hyperbole, simile, oxymoron, allusion, litotes, and metonymy. The imagery is visual imagery, auditory imagery, organic imagery, kinesthetic imagery, tactile imagery, and olfactory imagery. Another research was also conducted by Isa, Ali, Fadzillah, \& Kasbon (2017), they did analyzed the figurative expressions utilized in Taylor Swift's 1989 album. From thirteen songs which were analyzed, the findings showed that there are eleven kinds of figurative language found in Taylor Swift's 1989 album; synecdoche, irony, litotes, metaphor, simile, personification, hyperbole, metonymy, oxymoron, paradox, and symbol.

Regarding to the findings stated above, it proves that figurative language could attract the people's interest as the use of it can help people to convey literal meaning by using different way. Therefore, the researcher focuses this research on analyzing the figurative language and its meaning in a song lyric entitled "Firework" by Katy Perry. In which, there will be several theories stated by the experts in relation to the figurative language and one of it is based on Perrine (1982). These theories will be used in order to strengthen the result of the analysis.

Based on the background of this research, the statement of problem of this research is formulated in the following questions:

1. What are the types of figurative language found in Katy Perry's song entitled "Firework"?

2. What are the meaning of the figurative language found in Katy Perry's song entitled "Firework"?

Presented below are the objectives of this research:

1. Firstly is to find out the kinds of figurative language in the song lyric entitled "Firework" by Katy Perry.

2. Secondly is to find out the meaning of the figurative language in the song lyric entitled "Firework" by Katy Perry.

It is expected that the results of this research can give contribution in general and also in the field of education.

1. In general, it is expected that the result of this study will be beneficial for readers in general. Or in this case it might also be beneficial for the songwriters to help them get a better comprehension about the theory related to figurative language. So, they will avoid the mistake in using the figure of speech and could write and produce beautiful songs.

2. Practically, in the field of education it is expected that this research can give contribution for:

a. For English language learners who are interested in literature's subject, in terms of figurative language. It is hoped that they can have a better comprehension about how figurative language or figurative expressions could promote the indirect meanings which might be used by someone in their utterance. In particular, this study explains how Katy Perry has successfully used the figurative language in her songs to deliver meanings which can be understood by the hearer.

b. For English teachers in order to help them enrich their knowledge and comprehension towards kinds 
of figurative language and several theories in relation to that, so that they can use it appropriately adjusting to the context of English language.

\section{LITERATURE REVIEW}

\section{Definition of Figurative Language}

According to Kennedy (1979) as cited by Listiani (2015), figurative language is defined as the figure of speech which is used in a language. The figure of speech that is meant here is the art of saying utterance other than its literal meaning. This figure of speech is used by the speaker or writer in order to avoid the use of denotation words.

It is believed that figurative language could convey meaning which cannot be expressed exactly any other way. It could convey meaning in a great shorter time because it actualizes the meaning in imagery instead of expressing it abstractly (Potter, 1967) as cited by (Listiani, 2015). Furthermore, Perrine (1982) also stated that figurative language is defined as the way in which extra dimensions are added to the language. In a short definition figurative language is a different way of saying something other than its ordinary way to make the language sounds more beautiful.

Commonly the figurative language can be found in many kinds of literature's works like poetry, prose fiction, and also non-fiction. People who are interested in literature's subject use figurative language in order to make the result of their literature's work sounds more beautiful on the hearer. Furthermore, this chapter will discuss about the types of figurative language. They are allusion, allegory, hyperbole, irony, litotes, synecdoche, simile, metaphor, personification, metonymy, symbol, paradox, and oxymoron.

According to Perrine (1982), allusion is defined as the way to strengthen the idea of one's work with the idea of another work. Or in briefly, it can be said that allusion is an indirect reference to a person, place, thing or even idea of historical and cultural. However, the thing in which a person is referred to does not describe in detail. It only consists of comment, and the one who uses this kind of figurative language expects that the reader has enough knowledge so that she or he could grasp the meaning of this figurative language.

For example:

"Don't act like Romeo in front of her!"

"Romeo" is a reference to William Shakespeare's literature work "Romeo and Juliet". The character of Romeo represents a passionate lover of Juliet. Therefore, the speaker who used this kind of figurative language expects that the one who she/he speaks to would stop acting like a passionate lover in front of somebody.

Allegory is defined as a figure of speech which is used to disguise meaning rather than reveal it, or disguise it from somebody while revealing to others (Perrine, 1982).

For example:

"George Orwell's Animal Farm."

It is one of the most famous literature's allegories. It tells about group of farm animals who rise up, kick out the humans, and try to run the farm themselves. The hidden story behind this figurative language is about the Russian revolution.

According to Arp (2011) as cited by Siallagan, Manurung, \& Sinaga (2017), hyperbole is defined as "simply exaggeration, but exaggeration in the service of truth". It means that the speaker who uses this kind of figurative language does not really mean the utterance that he or she is saying, but the speaker is only overstating their statement.

For example:

"The girl was dying to get a new school uniform."

The word "dying" might refers to the condition in which the girl seemed already gave up in finding the school uniform for herself.

"The weather is so hot! It feels like I'm on fire." 
The phrase "I'm on fire" represents to the condition in which the speaker could not withstand the heat, so she/he wanted to express the feeling by using this figurative language.

According to McArthur (1996) as cited by Ain (2013), irony is defined as the usual meaning which contradicts to the words that have implication. In briefly, it can be concluded that irony represents the difference between the things that might be expected to happen to the thing which actually occurs. There are three types of irony; verbal, dramatic, and situational. For example:

"Students, you all are so discipline because you come to school and 9.00 o'clock."

The word "discipline" represents to the situation in which the students were actually late because they came to school at 9.00 o'clock meanwhile the lesson started at 7.30 am.

Litotes is defined as the way in which a speaker uses double negatives or even positive statement which is expressed by negating its opposite expressions in order to make someone's remarks forceful (Hornby, 2000).

For example:

"She is not a beauty queen."

The phrase "beauty queen" here used in order to represent that "she" was actually an ugly girl. Therefore, in order to avoid rough words the phrase "beauty queen" then chosen by the speaker.

According to Kennedy (1979) as cited by Listiani (2015), synecdoche is a kind of figurative language in which a part of something is used to represent the whole or the whole is used to represent a part.

For example:

"I won't let strangers come under my roof."

The word "roof" represents to the speaker's house in which the speaker forbids strangers to come to his/her house.

Simile is defined as the kind of figurative speech which is used to make comparison between two different things by using the word; like, as, than, similar to, resembles, or even seems (Perrine, 1982).

For example:
"My dad is as brave as lion."

"Lion" is known as the king of the jungle who is really brave, and tough. So "lion" was chosen by the speaker in order to make a comparison to represent that the speaker's dad is as brave and tough as a lion.

"Her heart is as hard as a stone."

"As hard as a rock" is used to represent that the one that the speaker's talking about is a person who is very cold, mean and also cruel to others.

According to Perrine (1982), metaphor is defined as the kind of figurative speech which is used as a means of comparing something which are essentially unlike without using the words "like", "as", "similar to" in which these words are used in simile.

For example:

"She is a pig."

"Pig" is known as an animal that loves to eat, sleep, has a lazy character and also big body. Therefore, the speaker said "she is a pig" instead of "she is as lazy as a pig" in order to represent that this "girl or woman" is totally a pig because this "woman or girl's" activities were only eating and sleeping so it makes this "woman" has a big body.

Personification is defined as a figure of speech in which the human's attributes are given to an animal, an object, or even concept. In another way it can be said that personification is a way in which the readers of the literature's work are asked to visualize the literal term in human form (Arp, 2011) as cited by (Siallagan, Manurung, \& Sinaga, 2017). For example:

"The skyscraper was so high that it seemed to kiss the sky."

Here, it is really impossible that the skyscraper could kiss the sky. However, the skyscraper is given the attributes of human by adding the phrase "kiss the sky" in order to describe that the skyscraper is truly high.

According to Arp (2011) as cited by Siallagan, Manurung, \& Sinaga (2017), metonymy is the kind of figurative language in which the name of an object is replaced by another which has association with it.

For example: 
"The white house will be announcing the decision at 12 pm."

"White house" refers to the place where the President of The United State of America stays.

Symbol is defined as an object or something else that could reflect something beyond the literal meaning (Divyani, 2004) as cited by Isa, Ali, Fadzillah, \& Kasbon (2017)

For example:

"The darkness."

It might represent a symbol of evil, fear or even loneliness.

Paradox is defined as the figure of speech in which a statement appears to be contradictory, but may include hidden truth (Kennedy, 1979) as cited by (Listiani, 2015). Or in briefly, it can be stated that paradox contains statement which has two opposite facts, but both the facts may be true.

For example:

"I close my eyes so I can see (Fugazi, Shut the Door)"

This is a piece of song lyrics by Fugazi entitled Shut the Door. Actually, the word "see" in this lyric was not used literally. Meanwhile, it is used figuratively in order to convey that by closing the eyes, this someone wants to "see" the truths.

According to Murthy (2003) as cited by Listiani (2015), oxymoron is defined as the figure of speech in which two opposite ideas are combined to create an effect. Commonly in oxymoron, an adjective will be combined with a noun to create contrasting meanings.

For example:

"The comedian was seriously funny."

"Seriously funny" is the phrase that is combined to create an effect. Therefore, the phrase "seriously funny" is used to illustrate that the comedian could make the audience laughing out loud.

"This is a genuine imitation of Rolex watch."
"Genuine imitation" is the phrase that is combined to create an effect. Therefore, the phrase "genuine imitation" is used to represent that the watch does not look like an imitation watch, but it looks like the real "Rolex" watch.

\section{Uses of Figurative language}

There must be certain reasons why figurative language is used in many kinds of literature's work like poetry, prose fiction, or even non-fiction. It is because in accordance to its definition in the above description that figurative language is defined as a different way of saying something other than its ordinary way to make the language sounds more beautiful (Perrine, 1982). Instead of making the language sounds more beautiful, there are also other reasons why figurative language is used in many literature's works; it is because figurative language affords imaginative pleasure, it is a way of bringing additional imagery into verse, and it is a way of conveying attitudes along with information. According to Encyclopedia Americana (1995) as cited by Listiani (2015), there are also other purposes of why figure of speech is used or found in many kinds of literature work; "to clarify meaning, to provide clear example, to stimulate emotions, and deepening the range of perception response to the world of objects and ideas."

\section{Previous Findings}

A research by Siallagan, Manurung, \& Sinaga (2017) analyzed the types of figurative language and imagery in Taylor Swift's songs. The researchers used qualitative descriptive method by examining the sentences exist in the song lyrics and the findings are presented in the form of paragraphs. There are thirteen songs examined by the researchers, and it is found out that there are eight types of figurative languages and six kinds of imagery used in Taylor Swift's songs. The figurative languages are personification, metaphors, hyperbole, 
simile, oxymoron, allusion, litotes, and metonymy. Meanwhile the imagery is visual imagery, auditory imagery, organic imagery, kinesthetic imagery, tactile imagery, and olfactory imagery. Then, the most figurative language and imagery used in Taylor Swift's songs are personification and visual imagery.

Another research by Listiani (2015) also analyzed the figurative language used in Taylor Swift's speak now album. These researcher used descriptive qualitative analysis to analyze and classify the sentences in every song's lyrics in Taylor Swift's speak now album. There are fourteen songs analyzed by the researcher. It is found out that there are seven types of figurative language which found out in Taylor Swift's songs in speak now album; simile, metaphor, hyperbole, personification, synecdoche, symbol, and oxymoron. Then, the dominant figurative language is hyperbole.

Ain (2013) also did the same research that is to analyze the figurative language used by Maher Zain in his album entitled "Thank You Allah". The researcher used qualitative method to analyze the data obtained. There are eight steps which had done by the researcher in order to analyze the data; listening to the songs, reading the song's lyrics, underlining the word which belongs to figurative language, identifying, classifies certain lyrics, coding, and making tables and also chart. Furthermore, it is found out that there are eleven types of figurative language found in Maher Zain album entitled "Thank You Allah". They are personification, metaphor, simile, alliteration, irony, litotes, euphemism, parallelism, antithesis, hyperbole, and synecdoche. The most dominant figurative language is hyperbole.

The same kind of research, however with different object of study also did by Wijayanti (2017). She did a research about analyzing the figurative language used in a novel written by Paulo Coelho. She applied descriptive qualitative method in which the data was collected by using documentation. The result of her research showed that there are four types of figurative language used in Paulo Coelho's novel, namely, comparison figurative language (simile, personification, metaphor, and allegory, opposition figurative language (hyperbole, antithesis, paradox, and apostrophe), linkage figurative language (metonymy, symbol, synecdoche, euphemism), and the last is repetition figurative language (antanaclasis, chiasmus, and repetition). Furthermore, from 115 data being analyzed, there are 56 pr $48,6 \%$ data of figurative language, there are 32 or $27.8 \%$ data of opposition figurative language, there are 8 or $7 \%$ data of linkage figurative language, there are 19 or $16.5 \%$ data of repetition figurative language includes. Meanwhile, the most dominant type of figurative language is the comparison figurative language in which the percentage is about $48,7 \%$.

Based on the above research, this study will present an analysis of figurative language found in the song lyric by Katy Perry entitled "Firework". The author of this article will also do the same thing as the above research. However, this research also has a difference from the previous research which is just to find out the types of figurative language used in certain songs, or even novel. Meanwhile here, the researcher will also find out the meaning of the figurative language used in Katy Perry's song entitled "Firework".

\section{METHOD}

\section{Research Method}

In this research, the researcher used descriptive qualitative method in order to analyze the figurative language used in the song lyric. In this case, the researcher will analyze the song entitled "Firework" by Katy Perry.

Descriptive analysis means to describe about what actually happen to procedures 
about method which are useful in research, or in briefly it can be said that descriptive analysis is used to describe the basic features of the data in a study. According to Moleong (2011) as cited by Listiani (2015), descriptive analysis does not apply the arithmetic calculation in detail because it only provides the summaries of the sample which has gotten. It employs technique of seeking, collecting, and analyzing the data instead of calculating the data.

Furthermore, according to Ary, Jacobs, Razavieh, \& Sorensen (2006) as cited by Ain (2013) "Qualitative studies are a distinctive type of research in education and the social sciences that can produce vivid and richly detailed accounts of human experience. These studies are based on social reality from that which underlies the standard quantitative approach to the study of education." One chooses a qualitative design, because it is the appropriate method for investigating the problem. The advantage of doing qualitative research is that it could increase the opportunity to develop new ideas and theories (Ospina, 2004).

From those above definition, it can be concluded that qualitative research would be appropriate to be used in finding, analyzing, and presenting the data of the research in a more detail way.

\section{Object of Study}

The object of the study is about figurative language or also known as figure of speech used in the song lyric entitled "Firework" by Katy Perry. Furthermore, based on what has been stated in review of related literature, there are twelve types of figurative language known in general based on theories stated by the experts. They are allusion, allegory, hyperbole, irony, litotes, synecdoche, simile, metaphor, personification, metonymy, symbol, paradox, and oxymoron.

\section{Subject of Study}

The subject of this research is the song entitled "Firework" by Katy Perry which exists in the album entitled "Teenage Dream."

\section{Sources of Data}

Source of data is used by the researcher in order to make the analysis becomes easier. Without source of data, the analysis is impossible to be done. Furthermore, the source of the data is a song lyric entitled "Firework" by Katy Perry. This song exists in her album entitled "Teenage Dream" which was produced in 2010. The source of the song lyric is taken from the website namely azlyrics.com.

\section{The Data}

The data of this research will be presented in written form, in which it will describe the results of the analysis related to the figurative language used in the song lyric entitled "Firework" by Katy Perry. Furthermore in presenting the data, the researcher may use table to ease the process of analysis so that the figurative language could be classified into its own kinds.

\section{Data Collection Method}

In this research, the researcher used study documentation as the way of collecting the data. Study documentation is defined as the way of collecting the data about case, transcripts, book, magazine, and so on (Arikunto, 1990) as cited by (Listiani, 2015). Here are several steps which are done by the researcher in order to observe the song lyric entitled "Firework" by Katy Perry. Firstly, the researcher reads the song lyric entitled "Firework". Secondly, the researcher selects and analyzes the sentences in the song lyric which belong to figurative language. Thirdly, the researcher writes down the result of the analysis. Lastly, the data is arranged based on its classification. 


\section{Technique of Data Analysis}

In analyzing the data, here are several steps which are followed by the researcher:

Identification

In this section, the data which has been collected by the researcher is identified based on the kinds of figurative language that exist and then it also focuses on the literal and nonliteral meaning of the figurative language found in the song lyric.

Classification

The researcher classifies every figurative language which is found in song lyric entitled "Firework" by Katy Perry based on the theory stated by the expert namely (Perrine, 1982).

\section{Data Analysis}

After the data of the figurative language being classified, the researcher then analyzes the figurative language found in Katy Perry's song entitled "Firework". Presented below are the steps of how the researcher analyzes the data:

1. First, listening to the song of Katy Perry entitled "Firework" from the album entitled "Teenage Dream."

2. Second, reading the song lyric of "Firework" by Katy Perry.

3. Third, underlining the words or sentences which belong to figurative language

4. Fourth, classifies every word or sentence that exists in the song lyric and categorizes it into its own types of figurative language as have been stated in the literature review.
5. Fifth, reanalyzing the figurative language that has been classified in order to avoid the mistakes by using the theories from experts. It is very important to be done by the researcher because in the process of classification, error might occur, that is why it needs to be reanalyzed to strengthen the argument.

6. Sixth, the result of the data analysis will be presented in the form of paragraphs in which table might also be provided in the result of the data analysis.

\section{RESULT AND DISCUSSION}

\section{Result}

This part showed the result of the data analysis which has been conducted by the researcher in order to find out the kinds of figurative language used in the song entitled "Firework" by Katy Perry and also the meaning that exists in each of the figurative language used in that song. Furthermore, the song lyric and the results of the types of figurative language used in that song can be seen in Figure 01 and Table 01. 


\section{"Firework"}

Do you ever feel like a plastic bag Drifting through the wind, wanting to start again? Do you ever feel, feel so paper-thin

Like a house of cards, one blow from caving in?

Do you ever feel already buried deep Six feet under screams but no one seems to hear a thing

Do you know that there's still a chance for you 'Cause there's a spark in you?

You just gotta ignite the light and let it shine Just own the night like the 4 th of July

'Cause, baby, you're a firework Come on, show 'em what you're worth Make 'em go, "Ah, ah, ah." As you shoot across the sky

Baby, you're a firework

Come on, let your colours burst Make 'em go, "Ah, ah, ah."

You're gonna leave 'em all in awe, awe, awe

You don't have to feel like a wasted space You're original, cannot be replaced

If you only knew what the future holds After a hurricane comes a rainbow

May be a reason why all the doors are closed So you could open one that leads you to the perfect road

Figure01. Firework Lyric
Like a lightning bolt your heart will glow And when it's time you'll know

You just gotta ignite the light and let it shine Just own the night like the 4 th of July

'Cause, baby, you're a firework Come on, show 'em what you're worth Make 'em go, "Ah, ah, ah." As you shoot across the sky

Baby, you're a firework

Come on, let your colours burst Make 'em go, "Ah, ah, ah."

You're gonna leave 'em all in awe, awe, awe

Boom, boom, boom

Even brighter than the moon, moon, moon

It's always been inside of you, you, you

And now it's time to let it through, -ough, -ough

'Cause, baby, you're a firework Come on, show 'em what you're worth Make 'em go, "Ah, ah, ah."

As you shoot across the sky

Baby, you're a firework

Come on, let your colours burst Make 'em go, "Ah, ah, ah."

You're gonna leave 'em all in awe, awe, awe

Boom, boom, boom

Even brighter than the moon, moon, moon Boom, boom, boom

Even briahter than the moon, moon, moon

Table 01. The Figurative Language found in "Firework"

\begin{tabular}{|c|c|}
\hline No & Lyric \\
\hline
\end{tabular}

1. Do you ever feel like a plastic bag

2. Drifting through the wind

3. Do you ever feel, feel so paper thin

4. Like a house of cards

5. One blow from carving in?

6. Six feet under screams but no one seems to hear a thing

7. 'Cause there's a spark in you?

8. 'Cause baby you're a firework

9. As you shoot across the sky-y-y

10. Come on, let your colors burst
Symbol

Hyperbole

Symbol

Simile

Hyperbole

Paradox

Symbol

Symbol

Hyperbole

Symbol 
11. You don't have to feel like a waste of space

12. You're original, cannot be replaced

13. After a hurricane comes a rainbow

14. Maybe you're reason why all the doors are closed so you could open one that leads you to the perfect road

15. Like a lightning bolt, your heart will blow

16. You just gotta ignite, the light, and let it shine

17. Just own the night like the 4 th of July

18. Even brighter than the moon, moon, moon
Simile

Metaphor

Personification

Symbol

Simile and Hyperbole

Symbol

Simile

Hyperbole
Table 01 shows the classification of the figurative language found in the song lyric entitled "Firework" by Katy Perry. Furthermore, the types of figurative language found are 7 symbols, 5 hyperboles, 3 similes, 1 personification, 1 metaphor, and 1 paradox. These figures of speech are applied in the song in order to create and store meaningful messages and also to make the song lyric sounds more beautiful so that the listener of the song will be interested listen to the song.

Furthermore, after knowing the types of figurative language used in the song lyric entitled "Firework" by Katy Perry, it is also important to know the literal meaning exist behind those figures of speech so that the listener or the reader will be able to grasp the messages exist in the song. Therefore, the researcher will also describe the meaning of those figures of speech and it will be presented below.

The analysis of meaning of figurative language exists in the song lyric entitled "Firework" by Katy Perry:

Lyric 1

"Do you ever feel like a plastic bag"
Meaning: "Do you ever feel like a plastic bag" belongs to symbol. "The plastic bag" that is meant here is not a plastic bag that is used to put things, but "a plastic bag" that is used in the song lyric is used as a symbolic to shows a thing. "A plastic bag" is used in the song lyric in order to represent the spirit of people. The lyric above wants to deliver a message that people who do not have spirit in their life is just "a plastic bag" that will be drifted by the wind. These people do not have any spirit to reach their dream, so they will only follow where the wind would take them to go.

Lyric 2

"Drifting through the wind, wanting to start again?"

Meaning: "Drifting through the wind" belongs to hyperbole. It belongs to hyperbole because the statement "drifting through the wind" illustrate how the plastic bag blown freely by the wind without knowing where the wind would take the plastic bag goes. The message that exists in this lyric is that it wants to illustrate about somebody who does not have any spirit in their life means that this somebody does not have any goal in their life. It also wants to represent about somebody who does Lingua Scientia| 54 
not have strong foundation so they will just follow where the time would take them to go.

Lyric 3

"Do you ever feel, feel so paper thin

Like a house of cards, one blow from caving in?"

Meaning: "Feel so paper thin" belongs to symbol. The paper thin that is used in this lyric actually has the same meaning like the plastic bag in the lyric 1. "The paper thin" is also used a symbolic to represent someone's spirit. The message that exists in this lyric is that when someone feels down, they will lose their spirit to continue their life.

Lyric 4

"Like a house of cards"

Meaning: "Like a house of cards" belongs to simile. It belongs to simile because there is the word "like" which is used to make a comparison between two different things; they are the person who lose the spirit is compared to the house of cards. This lyric is actually the continuation of the previous lyric. In which, it wants to illustrate about someone who loses the spirit to continue their life is considered as a house of cards. This someone actually has the power to stand by using their own feet and continue their life; however this person does not really have strong foundation that could help them to stand firmly when facing the problems. This someone tends to fall down when a problem comes to them.

\section{Lyric 5}

"One blow from caving in"

Meaning: "One blow from caving in" belongs to hyperbole. The statement "one blow from caving in" indicates an overstatement because it wants to show how the power of a blow could broke a house of cards. This lyric wants to represent how problem could make people fall down when they do not really have strong foundation and spirit in continuing their life.

Lyric 6

"Six feet under screams but no one seems to hear a thing"

Meaning: "Six feet under screams but no one seems to hear a thing" belongs to paradox. The previous lyric which is "do you ever feel already buried deep?" actually asks the listener, are they ever in a condition where they are facing a very big problem and feel really down. Then, it continues by "six feet under screams but no one seems to hear a thing" in which it wants to illustrate how people who are really in a very down condition and want ask for a help but no one could hear or even help them.

Lyric 7

"Cause there's a spark in you" Meaning: "Cause there's a spark in you" belongs to symbol. The spark, firework are used as symbolics that could represent the spirit. In which, the messages that exist in this lyric is that everybody has the chance to make themselves better if they have the urge to do or to change it. No matter how big the problems will come to us, when we have the urge to solve it, we will also be able to finish it.

Lyric 8

"Cause baby you're a firework

Come on, show 'em what you're worth

Make 'em go "ah, ah, ah"

As you shoot across the sky-y-y"

Meaning: "Cause baby you're a firework" belongs to symbolic. The word "firework" is used as a symbol that could represent someone's spirit. It has the message in which, it wants to tell the world that people need to show who they really are. People have to show what they have, in this case is their ability. There is nothing that needs to be afraid off because the spirit that we have will help us to

Lingua Scientia| 55 
handle our fear and help us to shine in front of others. Furthermore, the lyrics "Make 'em go "ah, ah, ah", as you shot across the sky- $y-y$ ", here the words which are compounded and repeated in order to create beautiful sounds and effects in a song. This lyric has the message to encourage people to let their spirit go and control themselves. When the spirit already controlled well, it will shoot across the sky which means people will be able to handle every problem that they have.

\section{Lyric 9}

"Come on, let your colors burst

Baby, you're a firework

Come on, let your colors burst

Make 'em go "Oh, oh, oh"

You're gonna leave 'em falling down-ownown"

Meaning: Come on, let your color burst belongs to symbol. The color that is meant here is not the name of colors in general like blue, purple, green, etc. Meanwhile, the color here is used a symbolic to represent someone's character or behavior. The message that exists in this lyric is that people do not need to pretend themselves to other people. They just just need to be who they really are. We do not need to hide our real character just be an open person.

Lyric 10

"You don't have to feel like a waste of space

You're original, cannot be replaced"

Meaning: "You don't have to feel like a waste of space" belongs to simile. It belongs to simile because there is the word "like" that is used to make a comparison of two different things. Meanwhile, you're original cannot be replaced belongs to metaphor. These lyrics have the message which wants to show that everybody is special without any exception. People have to be their own selves and do not ever comparing yourself to others because everyone has their own uniqueness.

Lyric 11

"After a hurricane comes a rainbow " Meaning: "After a hurricane comes a rainbow" belongs to personification. This lyric has the message to remind people that they do not need to worry about the problems that came to them. People have to believe that after a hurricane the rainbow will come. It means that good things are waiting for us after facing the problems. That is why people do not need to give up when problems come. People just need to go ahead and keep pursuing their dream.

Lyric 12

"Maybe you're reason why all the doors are closed

So you could open one that leads you to the perfect road"

Meaning: These lyrics belong to symbolic. The word "doors" belongs to symbol which indicates something. "Doors" are used as a symbolic that could represent "a way". The first lyric, "maybe you're reason why all the doors are closed" means that "we" are the reason of why our steps are stopped. "We" are actually the reason that cause the problems come to our life. We tend to underestimate ourselves. We tend to judge our own selves that we are weak that we are not capable in doing anything. That is why these lyrics want to encourage people to try to believe in their own selves so that we could open our own way that could lead us to reach our dream.

- $\quad$ Lyric 13

"Like a lightning bolt, your heart will blow" Meaning: There two types of figurative language in this lyric. They are simile and also hyperbole. Like a lightning bolt belongs to simile, meanwhile your heart will blow belongs to hyperbole. These lyrics mean the road that 
has been chosen will be like a bolt. It will be an amazing thing that people will see how great you are. Your heart will blow means that when you already got your own way you are going to be on fire.

Lyric 14

"You just gotta ignite, the light, and let it shine"

Meaning: You just gotta ignite, the light, and let it shine belongs to symbol. The light is used as a symbolic to represent a hope or spirit. The lyric has a message to encourage people to find the spirit and let it burn.

Lyric 15

"Just own the night like the $4^{\text {th }}$ of July" Meaning: "Just own the night like the $4^{\text {th }}$ of July" belongs to symbol. The $4^{\text {th }}$ of July here is the independence day of America. It is used to represent the freedom of ourselves. People will find the freedom after tackling down the problems that they have just like the $4^{\text {th }}$ of July.

Lyric 16

"Boom, boom, boom

Even brighter than the moon, moon, moon It's always been inside of you, you, you

And now it's time to let it through-oughough"

Meaning: These lyrics belong to hyperbole. "Boom, boom, boom" are the words which are compounded and repeated in order to create beautiful sounds. "Boom, boom, boom" here are the sound of the firework itself. In which, in this case it represents the sound of the spirit that exist in our self. "Even brighter than the moon, moon, moon" illustrates that our spirit shines every time even brighter than the moon itself. Therefore, people need to know who they really are, so people can build their own spirit and show it to other people.

\section{Discussion}

This part emphasizes about the data that are found and analyzed by the researcher. As what has been stated in the findings that after analyzing the data in the song lyric entitled "Firework" by Katy Perry, the researcher found out that there are several types of figurative language used in that song. They are symbolic, hyperbole, simile, personification, metaphor, paradox. Furthermore, in total, there are eighteen lyrics content are written by the songwriter by using the figurative language.

Furthermore from the analysis of the data, especially about the meaning of the figurative language used in the song lyric entitled "Firework" by Katy Perry, overall this song actually wants to deliver messages to the hearer or listener that they have to look deeper into their own selves in order to recognize who they really are. This song wants to encourage people to find the spirit in their life so that people could continue their life. This song wants to encourage people so that they do not give up in facing problems which are given to their life. Whether it is a small or a big problem, do not ever give up just keep going. Furthermore, the word "Firework" itself is used to represent the boom of the spirit. By writing this song lyric, it is expected that people will always keep their spirit shine and it has to be brighter than moon. By keeping our spirit shines, it is the only way that we can do to face and solve our problems. Nobody could help us expect ourselves. Therefore, we have to find the best way that could help us solving our problems.

The use of figurative language in the song entitled "Firework" makes the song sounds more beautiful and nice to be heard by the listener. By using several types of figure of speech, it makes the singer of the song could deliver the messages that exist in the song briefly yet in a meaningful way, so that the listener could catch the messages easily.

Lingua Scientia| 57 


\section{CONCLUSION}

From the findings and discussion above, it can be concluded that in the song lyric entitled "Firework", there are eighteen lyrics contain several types of figurative language. Those types of figurative language are symbolic, hyperbole, affiliation, simile, personification, metaphor, paradox, and also affiliation. The existence of these types of figurative language help the singer to deliver the messages exist in the song briefly yet in a meaningful way, so that it could help the listener of the song could catch the meaning of the song easily. Furthermore, the main message which exists in this song is about encouraging people to be optimist, never give up and believe in their own selves that they have the spirit to solve the problems that they have, so that they have the courage to stand by using their own feet and continue their life.

By doing research about figurative language, it is expected that the readers who read the result of this research especially students, teachers, or even the listener of the song itself could have a better understanding towards the types of figurative language and also how figurative language could cover literal meaning in a brief yet meaningful way.

\section{REFERENCES}

Ain, Q. (2013). An Analysis of Figurative Language in The Song Lyrics by Maher Zain. Cirebon: Syekh Nurjati State Institute for Islamic Studies .

Harmer, J. (2006). The Practice of English Language Teaching (3rd Ed). New York: Longman Publishing.

Hornby, A. (2000). Oxford Advanced Learner's Dictionary. New York: Oxford University Press.
Isa, N., Ali, A., Fadzillah, F., \& Kasbon, H. (2017). Are We Out of The Woods Yet? An Analysis of Figurative Expressions Utilized in Taylor Swift' 1989 Album. Journal of Humanities, Language, Culture and Business (HLCB), Vol. 1, No. 1, page 22-34, eISSN 01268147.

Listiani, H. (2015). An Analysis of Figurative Language Found on The Song Lyric by Taylor Swift's Speak Now Album. Salatiga: State Institute for Islamic Studies.

Ospina, S. (2004). Qualitative Research. London: SAGE Publication.

Perrine, L. (1982). Sound and Sense An Introduction to Poetry (6th Ed). United States of America: Harcourt Brace Javanovich, INC.

Semi, A. (2012). Metode Penelitian Sastra. Bandung: Angkasa.

Siallagan, S., Manurung, S., \& Sinaga, J. (2017). Analysis of Figurative Language and Imagery in Taylor Swift's Songs. Journal Anglo-Saxon, Vol.3, No.1, 55-67, ISSN: 23015292.

Wijayanti, L. (2017). An Analysis of Figurative Language Used in Paulo Chelho's Adultery Novel. Surakarta: Universitas Muhammadiyah. 